INEZ OKULSKA

Uniwersytet im. Adama Mickiewicza w Poznaniu

inez.okulska@gmail.com

\title{
DOUGLAS ROBINSON, CHARLES BERNSTEIN, VERSATORIUM I METONIMICZNA MIŁOŚĆ POWTÓRZENIA, CZYLI TROPY JAKO NARZĘDZIA KRYTYKI PRZEKŁADU ${ }^{1}$
}

\section{Abstract \\ Douglas Robinson, Charles Bernstein, VERSATORIUM and Metonymic Repetition, or Tropes as a Practical Tool for Translation Criticism}

The author proposes a new critical model of translation analysis: the method is based on translation tropics - an idea by Douglas Robinson presented in his book Translator's Turn - but it has been vastly modified and extended. Five tropes (irony, metonymy, synecdoche, hyperbole and metalepsis) describe five types of translators and their affective motivations for translational decision making: translator's affects toward the Other of the source text and culture. The article offers deeper insight into one of the tropes, i.e. metonymy. The analytical part presenting a practical gain from this theoretical tool is based on alphabetical translations of Charles Bernstein's work made by Peter Waterhouse and his VERSATORIUM group.

Key words: translation theory, literary translation, tropes, rhetoric, translation criticism

Słowa klucze: teoria przekładu, przekład literacki, tropy, retoryka, krytyka przekładu

${ }^{1}$ Artykuł ten prezentuje częściowe wyniki badań prowadzonych przeze mnie w ramach projektu Ttumacz wobec Innego - tropy i sygnatury realizowanego w programie ETIUDA 1 finansowanym przez Narodowe Centrum Nauki. Efektem badań była rozprawa doktorska, obroniona z wyróżnieniem na Wydziale Filologii Polskiej i Klasycznej UAM w Poznaniu 22 września 2015 roku. 
Żeby nie bronić zbyt zawzięcie swojego podziału i nie sprawiać wrażenia, że jestem do niego przywiązany, że weń wierzę, pozwólcie, że zakończę ten podrozdział zaproszeniem, otwartą zachętą, byście robili z tymi tropami, co tylko chcecie, łączyli je, scalali, rozszczepiali - cokolwiek. Sam nie zawsze jestem pewien ich funkcjonalności. Ale jedyny powód, dla którego je oferuję to przekonanie o tym, że mimo wszystko funkcjonują one lepiej niż wszystko inne, co do tej pory widziałem; a jednak nie są idealne, nigdy nie będą ani też być idealne nie muszą. To tylko narzędzia. Używajcie ich, jak chcecie, albo wrzućcie je do szuflady, niech się pokryją grubą warstwą kurzu (Robinson 1991: 181)².

To oświadczenie, nieco zaskakujące jak na dyskurs naukowy, pochodzi z opublikowanej w 1991 roku książki Translator's Turn Douglasa Robinsona, w której amerykański translatolog naszkicował autorską koncepcję krytyki przekładu, rozumianej jako nakierowany na osobę tłumacza (i jego somatykę) opis szukający zrozumienia dla (tropicznych) motywacji wyborów i strategii translatorskich.

Robinson postuluje w badaniach procesu przekładu zwrot ku osobie tłumacza, którego cielesność (rozumiana jako zdolność fizycznego odczuwania) ma znaczący wpływ na decyzje podejmowane w trakcie thumaczenia. Zarzuca on zachodniej myśli o przekładzie, ufundowanej na tradycji św. Augustyna, instrumentalizm i perfekcjonizm (por. Gray 1994: 178-179), czyli oczekiwania wobec tłumacza niewidzialnego, odczłowieczonego i pozostającego narzędziem do osiągania ekwiwalencji. Autor Becoming a Translator podważa także supermem ${ }^{3}$ ekwiwalencji obiektywnej, odgórnie narzuconej, dowodząc, że jest ona niemożliwa, niekonkluzywna i dlatego nie powinna stanowić kryterium oceny (a tym samym „celu”) przekładu. Zgodnie z postulatem sprzeciwu wobec instrumentalnego traktowania thumacza badacz proponuje więc przeniesienie punktu ciężkości teorii przekładu $\mathrm{z}$ oceny rezultatów na analizę procesu, z uwzględnieniem somatycznych motywacji tłumaczącego. Ale w przeciwieństwie do funkcjonalistycznych teorii (między innymi teorii skoposu) Robinson chce skupić się na tym, co nieuświadomione, podprogowe, idiosynkratyczne - nie ma więc tu mowy o sprecyzowanym celu przekładu, który byłby sformułowany czy umówiony i stanowił wyznacznik świadomie przyjętej strategii.

2 Jeśli nie zaznaczono inaczej, cytaty obcojęzyczne podaję w swoim przekładzie.

3 Robinson nie używa tego pojęcia, ale ma na myśli ekwiwalencję właśnie w rozumieniu supermemu Andrew Chestermana (por. Chesterman 1997: 7-14). Szerzej o koncepcji supermemów pisałam przy okazji duetu przekładowego Różewicz-Lachmann (por. Okulska 2015: 321-322). 
Translatolog odrzuca też dychotomię ciało-umysł, podkreślając ich nierozerwalny związek, i proponuje podział na to, co wewnętrzne, i to, co zewnętrzne, czy indywidualne i grupowe, z granicą wyznaczoną przez granicę ciała właśnie. Idiosomatyka oznacza doświadczenia, afekty, percepcję osobistą, ideosomatyka natomiast jest odpowiedzią thumacza na otaczające go (i programującego jego myślenie i zachowanie) normy kulturowe i społeczne. Za Kennethem Burkem Robinson rozpatruje tłumaczenie w sensie performatywnym (w opozycji do naukowego, wyłącznie konstatującego) jako dramę $e^{4}$ - indywidualne działanie, oparte na jednostkowych, idiosomatycznych motywacjach - która odgrywana jest na pewnej scenie (zespół uwarunkowań społeczno-kulturowych, motywacja ideosomatyczna) (por. Robinson 1991: 127; Burke 1962: 44-45).

Idąc tym tropem, Robinson podważa kategorię obiektywnej ekwiwalencji i proponuje jednocześnie pojęcie ekwiwalencji somatycznej, to znaczy takiej, w której tłumacz „czuje”, że dana fraza jest odpowiednia, a owo czucie jest wypadkową idio- oraz ideosomatyki. Niestety translatolog jest w swojej argumentacji niekonsekwentny i miesza pojęcia, bo od ciała thumacza przechodzi w sposób kryptohermeneutyczny do „ciała” tekstu, które tłumacz musi wyczuć:

jeśli nie poczujesz ciała tekstu wyjściowego, masz niewielką szansę na stworzenie fizycznie namacalnego i emocjonalnie żywego przekładu. Co najwyżej stworzysz tekst, który będzie sprawiał wrażenie wygenerowanego przez komputer: bez życia, bez emocji (Robinson 1991: 17).

Oprócz somatyki amerykański badacz zajmuje się również tropiką przekładu, i to ona jest drugim istotnym aspektem poruszonym w Translator's Turn, mającym służyć opisowi „hermeneutycznych narzędzi” skierowanych na tekst wyjściowy (tropy) oraz kulturę/język/odbiorcę oryginału ${ }^{5}$ (wersje - w sensie subwersji, dywersji, perwersji etc.). I to właśnie ta propozycja będzie punktem wyjścia dla moich dalszych rozważań. Tropikę tę Robinson opiera na sześciu tropach głównych w rozumieniu Harolda

${ }^{4}$ Pojęcie to zostało użyte w sensie metody odgrywania przypisanych ról, nie utworu scenicznego czy potocznie rozumianej sytuacji konfliktowej.

5 Świadomie będę stosować raczej kontrowersyjne dla translatologii pojęcie ,oryginału” w celu określenia tekstu, który podlega przekładowi, ze względu na interesująco płynne granice pomiędzy tekstem wyjściowym a docelowym oraz tym, co jednostkowe, oryginalne właśnie, a powielone, odtworzone, zawłaszczone. Oryginał jest tu (zmienną) funkcją, a nie immanentną cechą tekstu wynikającą z jego ontologii. 
Blooma i traktuje je jako obrony (ratios) przed wpływem oryginału ${ }^{6}$ (ale znów niekonsekwentnie rozumianego: niekiedy jako tekst, niekiedy jako normy i tradycje programujące oczekiwania wobec zadań tłumacza, a także jako autor tekstu wyjściowego). Jak prezentują się poszczególne tropy zaadaptowane do kwestii przekładu?

Proponując kategorię tłumacza ${ }^{7}$ metaforycznego, Robinson przywołuje definicję Burke'a (,metafora jest narzędziem pozwalającym na postrzeganie jednego w kategoriach [in terms of] drugiego") (137), by skorzystać z zawartej w niej figury „,narzędzia”: „tłumacz metaforyczny, zamiast podporządkowywać się abstrakcyjnemu ideałowi strukturalnej ekwiwalencji (...), może użyć metaforycznej ekwiwalencji jako narzędzia poetyki do wtłoczenia [bending] tekstu wyjściowego w tekst przekładu, do wygenerowania tekstu w języku docelowym, który będzie pozostawał w pewnym istotnym związku z tekstem wyjściowym" (138). Metonimia, co podkreśla Robinson, to także trop ekwiwalencji, ale o ile metafora mówi, że ,jedno jest drugim, o tyle metonimia oznajmia ostrożniej, że jedno i drugie są elementami tej samej całości” (138). Co za tym idzie, tłumacz metonimiczny działa ze świadomością, że owa „całość”, którą próbuje oddać w przekładzie, jest jedynie symbolicznym konstruktem ułatwiającym odtworzenie oryginału, a nie czymś, co należy oddać w pełni perfekcyjnie (140). Skoro synekdocha to trop reprezentacji, czyli (między innymi) zastąpienia całości przez jej część, to tłumaczenie synekdochiczne według Robinsona polegać ma na wyizolowaniu jednego elementu tekstu wyjściowego, który zostanie uznany za reprezentatywny i oddany w przekładzie (w rozumieniu próby zachowania relacji quasi-ekwiwalencji wobec wyjściowej całości) (153). Jako motywację tłumacza ironicznego autor Translator's Turn podaje negację możliwości przekładu jako takiego, która jednocześnie legitymizować ma translatorską swobodęironiczny tłumacz nie udaje, że jest w stanie dostarczyć transparentnego odwzorowania oryginału, więc pozwala sobie na zdecydowane interpretacje, własny idiom itp. (167 i n.). Z jeszcze większym rozmachem do oryginału pochodzi tłumacz hiperboliczny (Robinson mówi wręcz o przesadzie [exaggeration]), ale ze zgoła innych niż ironista powodów - próbując ulepszyć

${ }^{6}$ Bloom pisał „Krytyk retoryczny może traktować obrony jako zamaskowane tropy”, Robinson traktuje zaś tropy jako zamaskowane obrony (por. Bloom 2003: 11).

${ }^{7}$ Lub przekładu, bo te pojęcia płynnie się przenikają - tłumacz ,metaforyczny” (czy odpowiednio ,ironiczny”, ,metonimiczny” etc.) to taki, którego motywacja do podejmowania konkretnych działań w obrębie przekładu była z natury (i mechanizmu) metaforyczna (ironiczna, metonimiczna) w rozumieniu zaproponowanych definicji tych kategorii. 
tekst źródłowy w przekładzie, by w ten sposób móc go oddać w zasłużonej pełni (176). Tutaj koncepcja amerykańskiego badacza najbliższa jest myśleniu o przekładzie jako wy-tłumaczeniu. Ostatni trop-kategoria, jaką proponuje amerykański badacz, to metalepsis, choć Robinson przyznaje, że mimo wnikliwej lektury Mapy Blooma i mimo własnych rozpraw na jej temat wciąż nie wie ostatecznie, czym dokładnie jest metalepsis, a na pytanie, czym miałaby być jako narzędzie translatologiczne, odpowiada wymijająco - czym nie jest i nie będzie (niczym stałym, permanentnym, solidnym jak most pozwalający na bezpieczny i bezproblemowy transport na drugą stronę - por. 184). Tłumaczenie metaleptyczne mgliście łączy się u Robinsona $\mathrm{z}$ immanentną dla tego tropu koncepcją zaburzenia porządku czasu, mniej więcej skłaniając się ku refleksji nad modernizowaniem i archaizowaniem w przekładzie (por. 185).

Niestety główny problem amerykańskiego badacza polega na tym, że w swojej interdyscyplinarności Robinson próbuje sięgać po zagadnienia, co do których nie posiada ani kompetencji, ani narzędzi badawczych, wobec czego jego propozycje pozostają w sferze abstrakcyjnych idei. A wszędzie tam, gdzie kończy się teoria, Robinson angażuje potoczną, nienaukową empirię, najchętniej opartą na własnym doświadczeniu. Tak skonstruowane modele zdają się mało operatywne nawet dla ich autora, Robinson bowiem swobodnie, anegdotycznie dryfuje w swoich wywodach, przytaczając ciekawe przykłady translatorskich sytuacji, ale do ich opisu tak naprawdę nie angażuje własnych pojęć (a jeśli już, to tylko na zasadzie luźnej, niezobowiązującej relacji). W rezultacie podbudowa teoretyczna jest raczej dość przypadkowa - Pawelec mówi wręcz o „teoretycznym parasolu” (Pawelec 2012: 27), czymś w rodzaju zasłony dymnej, która oddali lub osłabi ewentualny zarzut o nienaukowy charakter teorii.

Niemniej - cytując jednego z recenzentów The Translator's Turn - „mimo niedociągnięć książka ta oferuje stymulującą lekturę" (Stark 1992: 868): stymulującą do dalszych poszukiwań, które zaowocowałyby stworzeniem spójnego modelu teoretycznego. W tym sensie propozycję Robinsona, zgodnie z jego własnym życzeniem, traktuję raczej jako inspirującą metaforę i rozpoczęcie dialogu niż jako projekt, na którym należy oprzeć swoje analizy. W mojej propozycji ujęcie indywidualnego aspektu thumacza nie oznacza - z konieczności wynikającej z braku narzędzi empirycznych - badania rzeczywistych procesów myślowych i emocjonalnych, jakie zachodziły podczas przekładu. Tropy i odpowiadające im afekty stają się więc na powrót kategoriami teoretycznymi, ale ufundowana na nich krytyka przekładu 
zorganizowana jest wokół osoby tłumacza i jego motywacji, a nie wokół oceny stopnia osiągniętej ekwiwalencji. W tym sensie staram się wypełniać postulat Robinsona dotyczący zmiany paradygmatu.

Poprzez rewizję i dopełnienie koncepcji Robinsona proponuję model takiej krytycznej lektury symptomatycznej, w której symptomatyczna, a więc podlegająca ,demistyfikacji” (czy wytropieniu), jest postawa thumacza wobec Innego: oryginału, jego poetyki, struktury, materialności, autora, języka źródłowego, kultury etc. Kluczem do rekonstrukcji postawy tłumacza (jego motywacji) - w ten sposób próbuję połączyć „,czynnik ludzki” z teoretycznymi kategoriami - będą odciśnięte w tekście sygnatury, które są śladem jego czytelniczej afektywnej reakcji wobec Innego. Z Innym oryginału konfrontowany jest tłumacz w sytuacji przekładowej. Dana postawa tłumacza będzie motywacją do konkretnych operacji na tekście - tropów. Proponowana przeze mnie koncepcja to pięć rodzajów takich tropów, podszytych właśnie afektem wobec Innego, które miałyby leżeć u podstaw dalszych działań tłumacza. Afekt ten jest próbą konkretyzacji, czyli nadania operatywnego, tekstowego charakteru działaniom somatycznym, o których wprowadzeniu do krytyki marzył Robinson.

Zgadzam się również z wysuniętym przez Robinsona postulatem holistycznego podejścia do przekładu jako całej sytuacji - dlatego też w swoich analizach „tropię” tłumacza widzialnego, sygnującego przekład swoją decyzją, idiomem, biografią, tłumacza obecnego w paratekstach, w przekładzie, w kulturze - tym bardziej w dobie poszerzonego dostępu do źródeł oraz ekspozycji zarówno autora, jak i tłumacza w przestrzeni publicznej (przez spotkania, wywiady, komentarze, blogosferę).

Tak rozumiana teoria tropiczna nie ma przedstawiać stanowiska wykluczającego i konkurencyjnego wobec dotychczas istniejących narzędzi krytyki przekładu - wręcz przeciwnie, mogą one służyć do opisu tego, co wydarzyło się w tekście w procesie przekładu, i jako takie stanowią wręcz niezbędny i operatywny punkt wyjścia do analizy tropów. Tropy te odpowiadają bowiem motywacjom, jakie mogły powodować takie, a nie inne strategie, na które zdecydował się tłumacz, ale motywacji tych należy zacząć szukać od tropienia sygnatur tłumacza w szeroko rozumianym tekście przekładu (szeroko - to znaczy z całą obudową peri- i epitekstów). Pytanie, na które próbuję odpowiedzieć, brzmi więc „dlaczego” i jest postawione w kontekście stosunku tłumacza do Innego. Nie chcę więc poprzestawać na, dajmy na to, konstatacji, że dokonana została egzotyzacja, lecz chcę podjąć próbę zbadania, co powodowało tłumaczem, by tę egzotyzację zastosować. 
Propozycję Robinsona nie tylko poszerzam więc o element afektywny i precyzuję na swój sposób, ale także redukuję do pięciu tropów, wykluczając z zestawu metaforę. Przekład jest metaforą, metafora jest przekładem - już choćby opierając się na przytoczonej przez Robinsona definicji Burke'a, założyć można, że mechanizm metafory rozumiany jako mówienie o jednym na zasadach drugiego [in terms of] wpisuje się w ogólną definicję każdego przekładu. Traktuję więc ów trop jako nadrzędny wobec pozostałych i tym samym będący poza klasyfikacją poszczególnych tropów charakterystycznych dla danej sytuacji przekładowej. Pokrótce omówię propozycję tak zmodyfikowanego modelu, by w dalszej części szerzej zająć się już tylko jednym tropem. Afektywne rozszerzenie tropów (ich dobór i definicja) przedstawione tu w skrótowej formie mogą się wydawać nazbyt arbitralne i przypadkowe, ale są wynikiem dłuższych badań nad możliwymi postawami tłumaczy wobec Innego oryginału.

1. Metonimia - miłość twórczego powtórzenia motywuje tłumacza, by zredukować Innego oryginału do mechanizmu kreacyjnego i twórczo od-tworzyć działania tego mechanizmu w języku docelowym. Przykładem takich działań są między innymi tłumacze literatury spod znaku OuLiPo czy liberatury.

2. Syndekdocha - tłumacz fetyszyzuje wybrany element Innego oryginału i uznaje go za pełnoprawną reprezentację całości, np. formę kosztem treści, treść kosztem formy. W pewnym sensie w takie działanie może się wpisać poszukiwanie dominanty translatorskiej.

3. Hiperbola - nadopiekuńczy tłumacz kolonizuje Innego oryginału i tłumaczy zgodnie z tym, co uważa za najlepsze dla niego, przy jednoczesnym wycofaniu się z roli zasłużonego (Bloomowska wzniosłość i groteska), na przykład tłumacząc w sensie wytłumaczenia, dopowiedzenia, wygładzenia składni. Jest to podejście, które nierzadko łączy się z ogromną estymą, jaką thumacz darzy autora.

4. Metalepsis - tłumacz ma do Innego oryginału stosunek abiektalny, Inny pociąga go i odpycha zarazem, i tym samym lokuje w niełatwym ,pomiędzy”, również na osi czasu. Metaleptyczne może być tłumaczenie archaizujące w czasach współczesnych. W przypadku translatorskiej serii Inny oryginału rozciągać się może także na poprzednie przekłady, będące tu kontynuacją Innego oryginału, wobec których metaleptyczny tłumacz próbuje się usytuować, starając się własne spóźnienie zamienić we wczesność. 
5. Ironia - tłumacz o silnym, rozpoznawalnym idiomie przejawiający wobec Innego stosunek wrogościnny, co oznacza, że z jednej strony podejmuje Innego jako gościa, $\mathrm{z}$ drugiej zaś ustawia go w hierarchii podległości, narzucając mu zasady panujące w swoim domu. Ironiczni tłumacze to nierzadko poeci o własnej silnej marce na literackiej scenie języka docelowego, którzy „zapraszają” do swojego języka tłumaczonych poetów, przy czym „swój język” oznacza tu zarówno język narodowy, jak i mocno ukształtowaną poetykę.

Nie twierdzę, że proponowane tu kategorie są chirurgicznie precyzyjne. Co więcej, przewrotność ludzkiego tłumacza może sprawić, że w obrębie jednego i tego samego aktu przekładu splotą się strategie przyporządkowane dwóm tropom. Niemniej jednak, jeśli stawką jest nowa jakość opowieści o sytuacjach przekładowych, uważam, że ryzyko wpisane w stworzenie nowatorskiej koncepcji (tym bardziej, że u źródeł jednak nieudanej) warte jest podjęcia. Przyjrzyjmy się zatem, czym jest i jak działa kategoria metonimicznej motywacji w przekładzie.

\section{Przekład metonimiczny. W poszukiwaniu skrytego mechanizmu, czyli miłość powtórzenia}

Don Kichot z taką mocą rozkochał się w rycerskich postaciach, ich honorach, zwyczajach i cnotach, że choć nawet z jego historycznej perspektywy instytucja tak pojmowanego rycerza była już nieaktualna, to jednak miłość, jaką ją obdarzył, wywołała w nim niepohamowaną potrzebę powtórzenia tego doświadczenia. Wyszczególnił pojedyncze elementy składające się na wizerunek błędnego rycerza, pojedyncze tryby i zębatki odpowiadające za właściwą pracę całego mechanizmu napędzającego chwalebne istnienie owego rycerza, i krok po kroku poddawał je powtórzeniu na samym sobie. A koło powtórzenia toczy się dalej, cały Don Kichot i jego losy stają się bowiem przedmiotem kolejnej repetycji (lub też jej próby) - i mam tu na myśli napisaną przez Jorge Luisa Borgesa historię Pierre'a Menarda, romantycznego szaleńca, który postanowił zostać autorem Don Kichota.

W świetle proponowanej tu tropicznej kategoryzacji motywacji przekładowych determinacja Menarda, podobnie jak determinacja samego Kichota, najbardziej wpisuje się w schemat metonimiczny. Menard nie chciał zdominować hiszpańskiej powieści swoim idiomem, nie fetyszyzował jednego wybranego jej elementu, nie próbował jej poprawiać, sądząc, że wie, co dla 
niej najlepsze, i wreszcie nie próbował metaleptycznie znaleźć się pomiędzy światem ekstra- i intradiegetycznym (o czym świadczy fakt, że zrezygnował $\mathrm{z}$ autobiograficznego prologu). To, co sobie zamierzył, zakładało dotarcie do mechanizmu napędzającego powstanie tej wybitnej powieści (do zestawu czynników składającego się na ten mechanizm) i ponowne wprawienie go w ruch, tak by móc stworzyć od nowa tę samą książkę:

Nie pragnął ułożyć innego Don Kichota - co byłoby łatwe - lecz właśnie Don Kichota. Zbędne byłoby dodawać, że nie myślał nigdy o mechanicznym przepisaniu oryginału; nie zamierzał go skopiować. Jego podziwu godną ambicją było stworzenie stronic, które zbiegałyby się - słowo w słowo i zdanie po zdaniu - ze stronicami Miguela de Cervantesa (Borges 1978: 40).

W Kierkegaardowskim ujęciu powtórzenie kojarzy się z odwzorowaniem czynności, stanu lub sytuacji raczej dotyczącej tej samej osoby w obu przypadkach - chęci przywołania tego, co już doświadczone. Ale ponieważ sytuacja przekładowa zakłada powtórzenie doświadczenia Innego, nie własnego (choć przecież zapośredniczonego w emocjach tłumacza), najbardziej interesował będzie nas tutaj właśnie ten rodzaj repetycji: pożyczonej, od-twarzającej ${ }^{8}$, jak wspomniane wskrzeszenie błędnego rycerza u Kichota czy próba napisania nowego-tego-samego Don Kichota i związany z nimi afekt metonimicznego przekładu. I choć duński filozof takiego rozróżnienia nie wprowadza, to wydaje się, że jego podział w istocie odzwierciedla ten dualizm. Kierkegaard operuje bowiem pojęciami ,wspomnienia” i ,powtórzenia”, o których pisze, że:

Powtórzenie i wspomnienie to ten sam ruch, lecz skierowany w przeciwne strony, gdyż to, co się wspomina, już było, powtarza się więc „do tyłu”. A właściwe powtórzenie to wspomnienie zwrócone ku przyszłości (Kierkegaard 2000: 17).

Ten ruch ku przyszłości możemy więc uznać za powtórzenie, które jest twórcze, aktywne, w przeciwieństwie do pasywnego wspomnienia. I tylko tak rozumiane powtórzenie - przekonuje dalej autor Przedmów - warte jest jakiekolwiek wysiłku:

Jedynie miłość powtórzenia jest prawdziwym szczęściem. Podobnie jak miłość wspomnienia pozbawiona jest niepokoju nadziei, zapierających oddech odkryć

${ }^{8}$ Taką formę zapisu pożyczam od tłumaczki artykułu Paula de Mana Autobiografia jako od-twarzanie (De Man 1986). 
przygody - lecz także i smutku wspomnienia. Przynosi za to błogosławioną pewność chwili. Nadzieja jest sztywna, ciasna i błyszczy jak nowa, jeszcze niewypróbowana odzież. Nie wiadomo zatem, czy właścicielowi jest w niej do twarzy i czy dobrze leży. Wspomnienie zaś jest ubraniem znoszonym, które choć nadal piękne, stało się za ciasne, bo właściciel wyrósł był z niego. Powtórzenie jest ubiorem nie do zdarcia, w sam raz dopasowanym, ani nie uciska, ani nie spada (Kierkegaard 2000: 18).

W obu przypadkach mowa o redukcji do pewnego mechanizmu po to, by powtórzyć jego kreacyjne działanie. Bloom mówi wręcz o „metonimicznej regresji do źródeł” (Bloom 2003: 16), jednocześnie przypominając, że trop metonimii to:

zmiana imienia, czyli podstawienie jakiegoś zewnętrznego aspektu rzeczy w miejsce rzeczy samej, przemieszczenie oparte na przyległości, które powtarza to, co przemieszczone, lecz zawsze nieco słabszym tonem (Bloom 2003: 24) ${ }^{9}$.

Tłumacz synekdochiczny, przypomnijmy, fetyszyzuje jeden z elementów oryginału i tłumaczy go, stawiając go w pozycji reprezentanta całości, dokonuje zatem jej redukcji. Strategia metonimiczna również opiera się na redukcji, ale nie stanowi ona celu, lecz zaledwie etap przejściowy. Inny oryginału zostaje ,zredukowany” do mechanizmu, który leży u podstaw tekstu wyjściowego - mechanizmu narracyjnego, formalnego lub jeszcze innego, i to on zostaje ,przetłumaczony” w sensie, jaki zawiera się w słowie „translacja”, czyli ruch w przestrzeni, przeniesienie z jednego miejsca do drugiego, w tym wypadku z jednego języka do drugiego, by tam ponownie zadziałać. Operację tę można porównać do transplantacji organu, którego zadaniem jest odtworzenie dawnych funkcji w nowym organizmie ${ }^{10}$. Zadaniem tłumacza nie jest przełożenie sensu (czymkolwiek ów sens jest) na

9 Ów „słabszy” ton w kategoriach przekładoznawczych potraktowałabym nie tyle wartościująco, ile raczej jako wyznacznik zachowania umownego, tradycyjnego układu sił w relacji autor - thumacz.

${ }^{10}$ Metafora ta umownie kontynuuje oczywiście uproszczenie zawarte w myśleniu o przekładzie jako transporcie sensów z punktu A do punktu B. Przesłankę tę Andrew Chesterman wlicza w poczet ,pięciu przekładowych supermemów”, słusznie zauważając, że tak naprawdę sensy ,przeniesione” do punktu B, czyli do języka i kultury docelowej, jednocześnie zostają w punkcie A, czyli tekście oryginalnym, i mają się dobrze. Gdyby bowiem zgodnie z obiegową metaforą ruchu ukierunkowanego source - target potraktować rzecz dosłownie, przekład musiałby równać się unicestwieniu oryginału (Chesterman 1997: 20). W tym sensie przeszczep komórek macierzystych - jeśli chcemy pozostać w obrębie metafor medycznych - mógłby się okazać nieco trafniejszym porównaniem. 
język docelowy, lecz wprawienie w ruch języka docelowego w taki sposób, by skonstruował na nowo (odtworzył, powtarzając) ów sens.

Przekład metonimiczny, motywowany miłością prospektywnego (skierowanego ku przyszłości) powtórzenia, jest dla tłumacza niczym szansa na stworzenie nowej wersji oryginalnego tekstu. Świadomie używam określenia „wersja": w przypadku takich przekładów w aparacie paratekstualnym już na okładce lub w obiegu krytycznym - najczęściej pojawia się pojęcie wersji lub wariacji. Problem owej ,wersji” polega na niejasnym określeniu granic przekładu, które pozwoliłby jednoznacznie stwierdzić, kiedy tekst jest jeszcze tłumaczeniem, a kiedy już zaczyna się przepisanie, zawłaszczenie, adaptacja czy właśnie wersja. Robinson również przygotowuje się na ten terminologiczny zarzut, ilustrując metonimiczne thumaczenie hipotetycznym przekładem wiersza The Bells Edgara Allana Poe, w którym tłumacz zredukowałby ów wiersz do kreacyjnego mechanizmu fonetycznego, by „odegrać" w nim przekład w języku docelowym:

(wówczas) pojawi się tradycyjny zarzut, że to nie przekład. Że co najwyżej można go nazwać „wariacją” (...). Taki zarzut wywodzi się z restrykcyjnej ideosomatyki zachodniej myśli o przekładzie, zgodnie z którą, jak to ujął Eugene Nida w tytule jednego z rozdziałów swojej książki From One Language to Another „Przekładać znaczy przekładać znaczenie”. Metonimiczne (tropiczne) podejście do przekładu nieustannie przypomina nam jednak o tym, że sens nie jest jedynym elementem, do którego tekst wyjściowy daje się zredukować (Robinson 1991: 144).

Akapit wcześniej Robinson sugeruje, że za przekład metonimiczny uznać można tłumaczenie słowo-w-słowo czy sens-zdania-w-sens-zdania, coraz bardziej rozszerzając zakres jednostki, która będzie podstawową, by później przywołać radykalne przykłady modyfikacji, jak choćby te u Celii i Louisa Zukofsky. Tłumacząc pieśni Katullusa, „podążali” oni - jak sami twierdzą - za „dźwiękiem, rytmem i składnią łaciny”, próbując oddać nie tyle „literalne” znaczenie, ile „znaczenie liter” utworu rzymskiego poety (Robinson 1991: 145).

Ten typ myślenia o redukcji do mechanizmu wydaje mi się wartym uwagi i funkcjonalnym narzędziem analizy przekładu. Włączanie przekładu słowo-w-słowo w jego obręb jest jednak o tyle dyskusyjne, że nie odnosi się do pojedynczego mechanizmu konkretnego tekstu, a do ontologii języka naturalnego, każdego języka, i z punktu widzenia literatury i jej perypetii może być zbyt ogólne: zamiast cokolwiek tłumaczyć, wprowadzi kolejne 
piętra metafory. Poza tym istnieje niebezpieczeństwo, że postulat Robinsona legitymizowałby przekład, który ani na poziomie znaczącego, ani znaczonego nie odpowiada oryginałowi, bo jedyna koherencja dokonuje się poprzez sam fakt, że istnieje „mechanizm” znaczącego/znaczonego w języku.

Reasumując, w mojej propozycji tropów przekładowych motywacją tłumaczenia metonimicznego jest miłość powtórzenia od-twarzającego, prospektywnego. Powtórzenie to zakłada cofnięcie się do źródeł, redukcję tekstu oryginalnego do mechanizmu kreacyjnego i wprawienie go ponownie w ruch przy użyciu języka docelowego (lub innego medium w przypadku przekładu intersemiotycznego). Mechanizmem kreacyjnym nie musi być znaczenie rozumiane jako arbitralna relacja signifiant i signifié.

\section{Poza zasadą znaczenia - przekład alfabetyczny grupy VERSATORIUM}

VERSATORIUM to grupa młodych badaczy zrzeszonych przy Instytucie Komparatystyki Uniwersytetu Wiedeńskiego. Grupa ta zawiązała się w 2011 roku wokół konwersatorium poświęconego poezji i translacji prowadzonego przez Petera Waterhouse'a. Austriacki poeta i pisarz zaproponował zajęcia $\mathrm{z}$ thumaczenia poezji, na których grupowo zajmowano się przekładem w teorii i praktyce - badając, omawiając i thumacząc teoretyczne i krytyczno-przekładowe teksty m.in. z kręgu amerykańskiej poezji nurtu $\mathrm{L}=\mathrm{A}=\mathrm{N}=\mathrm{G}=\mathrm{U}=\mathrm{A}=\mathrm{G}=\mathrm{E}^{11}-\mathrm{w}$ wymiarze $30-40$ godzin tygodniowo. Intensywność odbioru jest jednym z programowych założeń grupy - „ze zmęczenia i wycieńczenia mogą się zrodzić zupełnie nowe rzeczy” (Grillmayr 2013). Szeroko zakrojony był również zakres materiału:

Tłumaczyliśmy wszystko, co wpadło nam w ręce, wszystko, co było wewnątrz i na zewnątrz książki, nie tylko poezję - wszelkie symbole i znaki również

${ }^{11}$ Należeli do niego między innymi Lyn Hejinian, Bob Perelman, Bruce Andrews, Susan Howe czy Charles Bernstein. Ten ostatni w 1983 roku wygłosił na konferencji Modern Language Association referat Akademia w niebezpieczeństwie: William Carlos Williams napotyka $M L A$, będący krytyką konsumeryzmu, propagowania literatury grzecznej i uładzonej i przemilczanie radykalnej awangardy. Utwory autorów zrzeszonych w tej grupie różniły się poetyką - od abstrakcyjnej po alegoryczną - ale łączy je to, że ,zajmują się nie światem jako miejscem - z całym jego inwentarzem natury i kultury - lecz światem jako napięciem różnych kontekstów, w którym język nie jest narzędziem opisu rzeczywistości, a efektem wymiany znaczeń” (Marcinkiewicz 2011: 52). 
podlegały przekładowi. Interesowała nas materia, która nie może być przełożona (Zhou 2014).

Rzeczywiście, publikacja, która powstała w wyniku spotkań - również wyjazdowych ${ }^{12}$ - wpisuje się w założenia liberatury (choć to pojęcie nie jest używane przez autorów): sensotwórcze są tu nie tylko teksty, ale i kroje czcionek, rozłożenie tekstu na stronie, forma okładki. Jej czwarta strona zamiast takich tradycyjnych elementów jak blurb czy parateksty wydawnicze zawiera jednozdaniowy wiersz będący swoistym komentarzem do formy książki w dobie cyfryzacji. Otóż znana choćby z Google Books informacja o tym, że dana strona jest celowo niezapisana (w przypadku maszynowej digitalizacji to konieczna uwaga, by czytelnik nie miał wątpliwości, że nic nie zostało przypadkiem pominięte): This page Intentionally left blank została sprafrazowana jako This Poem Intentionally Left Blank (Ten wiersz celowo został niezapisany).

Nazwa zrzeszenia wypełnia postulat zabawy językiem: konwersatorium zajmujące się wierszem i wersem to wersatorium. Poza tym, jak twierdzą jego członkowie, w nazwie tej pobrzmiewa również angielski przymiotnik versatile (,wszechstronny”, ,uniwersalny”), który także odpowiada ambicjom tłumaczy. Ta wszechstronność oznacza między innymi otwarcie na niekonwencjonalne metody, na wymianę myśli, na ,inkluzyjność” w procesie thumaczenia:

każdy rodzaj aktywności jest dozwolony wewnątrz naszego konwersatorium jeśli ktoś ma ochotę się zdrzemnąć, poprzestawiać meble, poczytać sobie inny wiersz lub powiedzieć o czymś, co zupełnie nie jest związane z tym, o czym akurat rozmawiamy, ma do tego prawo. [Nasza działalność translatorska-I.O.] jest wysoce inkluzyjna przy założeniu, że nie produkujemy żadnych [ostatecznych - I.O.] rezultatów ${ }^{13}$.

12 Grupa tłumaczy miała organizować wyprawy do „progów” (Waterhouse używa określenia threshold, które zaraz tłumaczy niemieckim Schwelle) Europy, stref zagrożonych konfliktem politycznym i zbrojnym. Celem tych wyjazdów było poznanie źródeł i mechanizmów nieporozumień, a więc sytuacji komunikacyjnych, w których prymat znaczenia został zniesiony, bo nie spełnił swojej funkcji.

${ }^{13}$ Przekład transkrypcji wypowiedzi Petera Waterhouse'a nagranej podczas seminarium, które odbyło się na Uniwersytecie Harvarda 9 kwietnia 2014 roku, pod tytułem The Versatorium Playbook: How to Do Things with Translation? 
Brak rezultatów jako efekt procesu przekładu (czy lektury w ogóle) jest jednym z programowych haseł VERSATORIUM. Tłumacze ci zakładają, że znaczenie, podobnie jak myślenie, nie prowadzi do żadnych ostatecznych rozwiązań, jest aktywnością nieskończoną, podatną na nieustające rekonfiguracje, skojarzenia, na ciągłość. Taka postawa czytelnicza, radykalizująca Derridiańską koncepcję iterowalności, pozwoliła tłumaczom zmierzyć się z poezją Bernsteina, nierzadko wystawiającą znaczenie rozumiane jako komunikat na próbę materialności języka. Spotkanie wiedeńskich tłumaczy z amerykańskim poetą zaczęło się od wiersza Johnny Cake Hollow (With Strings: Poems, 2001), który jest zapisem - w myśl Waterhouse'a tylko jednym z wielu, nieostatecznym - potencjału języka, możliwości swobodnego uszeregowania liter i dźwięków, w oderwaniu od imperatywu znaczenia niesionego przez konkretny język narodowy:

\section{Johnny Cake Hollow}

Xo quwollen swacked unt myrry flooped

Sardone to fligrunt's swirm, ort Jirmy plaight org garvey swait ib

Giben durrs urk klurpf. Sheb

Boughtie bloor de dazzy dule dun

Fruppi's ghigo's gly, jud

Chyllrophane jed jimmsy's cack -

Exenst aerodole fump glire. Eb

Horray bloot, ig orry sluit neb

Nist neb ot neb gwon. Shleb

Atsum imba outsey burft allappie

Merp av ords. Een ainsey swish

Ien ansley sploop ughalls dep dulster

Flooge, ig ahrs unt nimbet twool

Begroob, ig ooburs quwate ag blurg.

Członkowie VERSATORIUM, początkowo zafascynowani nieprzekładalnością wiersza pod kątem ekwiwalencji brzmieniowo-znaczeniowej, szybko doszli do wniosku, że jest on w zasadzie „,bardzo aktywny” (w tym sensie, w jakim myślenie jest aktywnością), a zatem ,wysoce przekładalny, ponieważ wiersz sam w sobie sugerował znaczenie w każdym punkcie każdego wersu. Dlatego jego przekład był nie tylko możliwy, ale też konieczny"14

${ }^{14}$ Przywołuje to znowu Derridiańską koncepcję oryginału błagającego, domagającego się przekładu. 
(Zhou 2014). Co nie znaczy, że tłumacze postanowili zaoferować swoim czytelnikom gotowe sensy: jak mówią, ,,przekład jest rodzajem komentarza. Nie oferujemy znaczenia (meaning). Jeśli chcesz mieć znaczenie, musisz je sam sobie dodać" (Zhou 2014).

W jedynej dotąd książkowej publikacji VERSATORIUM: Charles Bernstein: Gedichte Und Übersetzen (Wiedeń 2013), pomieszczone zostały zarówno oryginalne teksty amerykańskiego poety (i jak się później okaże nie tylko jego), tłumaczenia, oryginało-przekłady (o czym w dalszej części artykułu) oraz komentarze tłumaczy czy też teksty, które można uznać za zapis pośrednich etapów procesu przekładu. Wersji tłumaczenia wiersza Johnny Cake Hollow jest w książce aż cztery, a jedna z tłumaczek, Julia Dengg, w osobnym tekście dzieli się własnym systemem przekładowej lektury:

Czytam wiersz Johnny Cake Hollow. I pośrodku wiersza widzę - nie mogę nagle przecież oduczyć się niemieckiego - w słowie jud słowo Jude (Żyd). I od słowa Jude skaczę - przeskoków myśli też nie mogę się oduczyć - do hebrajskiego. Zaglądam więc do słownika - nie znam hebrajskiego - i trafiam na słowo כאב, transkrybowane ke'ev. Myślę więc - nie mogę nagle oduczyć się angielskiego - że ke'ev brzmi jak cave, Höhle. Dowiaduję się, że to hebrajskie słowo znaczy „,ból”. I zaraz przychodzi mi na myśl, że przecież Höhle to po angielsku też hollow. W głośnej lekturze słyszę później, że angielskie słowo „ból” też się pojawia w wierszu: w słowie Chryllophane, które autor wymawia jak crylo-pain. Cieszę się, że oduczyłam się dążenia do logicznych, wytłumaczalnych wniosków. (...) Granice eksplodują. A czytanie staje się szaleństwem (Dengg 2013: 10-11).

Waterhouse nazywa ten rodzaj przekładu alphabetical translation ${ }^{15}$, przekładem alfabetycznym, literowym - ale nie literalnym, bo w przeciwieństwie do niego nie skupia się na dosłownym (literalnym) znaczeniu, tylko na znaczeniach liter jako elementów audiowizualnych, które można układać w szeregi. Takie myślenie - i znajdzie ono zastosowanie w niemal wszystkich pomieszczonych w tomie przekładach, we wszystkich ich wymiarach - oparte jest na koncepcji, skądinąd metonimicznej, zadania tłumacza Waltera Benjamina. Benjamin uważa bowiem, że zadanie to nie polega na przekazywaniu, lecz na dopełniającym odtwarzaniu, wolnym od imperatywu ekwiwalencji na poziomie semantycznym (w tym sensie,

15 Waterhouse użył tego określenia podczas wykładu w Mahindra Humanities Center na Uniwersytecie Harvarda, wygłoszonego 3 listopada 2014 roku w ramach cyklu Rethinking Translation. 
w jakim lingwistyczne szkoły przekładu traktują przekład jako poszerzony proces przenoszenia komunikatu), oraz że tłumacząc, należy cofnąć się do „przedjęzyka”, do mechanizmu kreacyjnego właśnie, i w nim „odgrywać” tekst przekładu. Słowa Benjamina to dobry komentarz do programych założeń „alfabetycznego" (czyli de facto metonimicznego) przekładu lingwistycznej poezji Bersteina, jaki uprawia VERSATORIUM:

Co bowiem „mówi” wiersz? Co komunikuje? Bardzo niewiele temu, kto go rozumie. Tym, co w nim istotne, nie jest komunikat, nie jest wypowiedź. Tymczasem przekład, który pragnie przekazywać, mógłby przekazać jedynie komunikat - czyli to, co nieistotne (Benjamin 2011c: 27).

Wiersz pozostaje w zasięgu percepcji zmysłowej - wzroku i słuchu (przy głośnej lekturze $)^{16}$, i choć trudno go ,zrozumieć”, tj. zdekodować sensy, to, jak się okazuje, nie sens (jako komunikat) jest celem takiego przekładu, podobnie jak nie komunikat napędza lekturę oryginału. Metonimicznym gestem tłumaczka dąży więc do powtórzenia - przez powrót do źródeł - mechanizmu rządzącego wierszem oryginalnym. A w poezji Bernsteina wiersz „,nie powinien być jak droga, wzdłuż której prowadzony jest czytelnik, lecz niczym ogród lub puszcza, w której każdy odbiorca może na nowo szukać własnych dróg" ${ }^{17}$. Stawką jest więc ponownie aktywność, nieustające poszukiwanie sensu, bez gwarancji, ale też bez konieczności jego odnalezienia, pobudzający tryb nigdy ostatecznie nie dokonany.

Tłumaczka pozwala się ponieść słowom i kontyngencji ich znaczeń każdy sens jest tu wymienny, nieostateczny i konkurencyjny, tym bardziej, że otwarty na konotacje interlingwalne. Potencjał relacyjności uznaje więc Dengg za mechanizm warty ponownego wprawienia w ruch w przekładzie - i jest

${ }^{16}$ Istniejące pojęcie przekładu sensualnego, które proponuje klasyfikację ze względu na zmysły aktywizowane w procesie tłumaczenia, skupia się niemal wyłącznie na zmysłach jako przekaźnikach - urządzeniach „wejścia” i „wyjścia”, pomijając ich sensotwórczą rolę. Przekład literatury traktowany jest tu a priori jako wizualny, bo nawet mimo realizacji głosowej ,zasadnicza wizualność tłumaczenia pisemnego nie ulega wątpliwości”, i owa wizualność jest jedynie narzędziem do odczytania (dosłownie) sensów w tekście. W powyższym przykładzie thumaczenia okazuje się jednak, że zmysły są, owszem, medium, ale w myśl McLuhanowskiego hasła medium is the message, bo to ich funkcjonalność zastępuje tu logocentryczne znaczenie. Por. M. Kaźmierczak, Zmysty w procesie i odbiorze thumaczenia, hasło stanowiące część projektu „Sensualność w literaturze polskiej” realizowanego przez IBL PAN pod kierunkiem W. Boleckiego.

${ }^{17}$ Cytat pochodzi z materiałów towarzyszących publikacji książki, przygotowanych przez wydawnictwo Korrespondenzen. 
to założenie, które wpisuje się w myślenie Bernsteina o własnej poezji. Bernstein twierdził bowiem, że jego wiersze „są językowymi kapsułami czasu, lingwistycznymi dioramami, gdzie każda fraza jest hiperlinkiem do dalszej ekspozycji” (Marcinkiewicz 2011: 52).

\section{Metonimiczne powtórzenie powtórzenia, czyli przekład przekładu}

W omawianej publikacji przekładowej grupy VERSATORIUM pojawiają się nie tylko oryginalne wiersze Charlesa Bernsteina, ale również oryginały wierszy amerykańskiego poety. Rozróżnienie to możliwe jest dlatego, że przekładowy charakter niektórych utworów został odpowiednio oznaczony. Paratekstualna obudowa tomu Gedichte Und Übersetzen jest jednak, jak już sugerowałam, na wskroś liberacka - semantycznie autonomiczna, przemyślana i pod wieloma względami świadomie nienormatywna. Tytuły poszczególnych tekstów zajmują najwyższą pozycję na stronie (jeśli przyjmiemy dominujący na świecie porządek linearnej lektury - od góry do dołu), z wyjątkiem przekładu wiersza Cover Me Up for I Cannot Myself Cover (142), którego tytuł Verstecke denn mich finde ich selbst mir nich Deckung (143) znajduje się pod tekstem tłumaczenia. Poza tym jednym odchyleniem można więc uznać, że paratekst tytułu został potraktowany tradycyjnie.

Informacja o nazwiskach - zarówno autorów, jak i tłumaczy-zdaje się jednak już performatywną odpowiedzią na obecny w dyskursie translatorskim zarzut co do deprecjonowania tłumaczy poprzez użycie w ich nazwiskach mniejszego stopnia pisma niż w nazwisku autora, którego przyjęło się eksponować na pierwszym miejscu. Tutaj bowiem na marginesie strony są podane dwu- lub trzyliterowe inicjały zapisane tym samym krojem i rozmiarem czcionki, zawsze minuskułami. Przy inicjałach „,cb”, czyli Charlesa Bernsteina, pojawia się dodatkowo system ikon, wyjaśnionych na końcu książki za pomocą legendy, oznaczających odpowiednie tomy poetyckie, z których pochodzą oryginalne wiersze. Obok tekstów przekładów, których oryginałów nie opublikowano w tomie, pojawia się ikona, w końcowym indeksie natomiast odpowiadające im wiersze Bernsteina wraz ze źródłami.

Taka paratekstualna koncepcja umożliwia dodatkową grę z normatywną ekspozycją przekładu i świadomością czytelniczą opartą na tradycyjnym rozumieniu hierarchiczności w relacji autor - tłumacz oraz oryginał - przekład. Na stronie 154 pojawia się tekst zatytułowany der und die, stronę obok dew 
and die, na następnej stronie zaś tau und tod, wszystkie trzy formalnie bardzo zbieżne, złożone bowiem z trzyliterowych wyrazów wpisanych w matrycę o wymiarach 13 pól x 26 pól (ej [Ernst Jandl], w: Bernstein 2013: 154):

der und die

kam der und die kam und die kam vor ihm ins tal und das war der ort und die sah hin und der und tat das oft und war müd und bös und wie eis und sah hin und her bis der kam der ins tal kam und nun los und das eis weg und der kam und der kam nah und kam ihr nah und war bei ihr und war nah bei ihr und sah auf ihr hin und her und die war wie für ihn war für ihn ist was für ihn ist muß mit und den hut und wie der den zog und zog aug bei aug auf ihr hin und her und ihr kam der ist wie ein ist was das ist was das ist für uns nun los und gib wie das eis weg süß und küß bis ans end der uhr und tag aus aug und ohr weg nur gut und naß und süß tau mit rum und nun los bot den arm und gab ihm den und das ohr und das auf und süd und ost und zog mit ihr mit ihm mit und das tor war los und die tür und der tag weg mit eis und müd und wut und hut und der ihr und die ihm und sog kuß aus kuß und hob und lud sie auf das ist gut ist für uns und los und ihn biß und der riß und zog und die ihn und bot ihm naß und süß tau mit rum und sog was der und der lag auf ihr und zog und tat und riß und biß und sog und ihr arm und das auf süd und das ohr die tür zur see und das amt aus und tot und wer vor mir ist weg ost weg nur ich auf hin und her hin und hun her hin her hin her bis rot und süß und wut die see ins tal riß und goß und den ort naß und müd lag auf uns

Sygnatury znajdujące się przy wierszach to (w kolejności podanych tytułów): ej, cb oraz mr. Znawcy poezji konkretnej rozpoznają w powyższym utworze wiersz Ernsta Jandla. Za pomocą nietypowego staccato, wywołanego przez nagromadzenie jednosylabowych wyrazów, spotęgowanego powtórzeniami zarówno obrazów, jak i schematów syntaktycznych (np. ,i zbliżył się do niej i był blisko niej i spojrzał”), utwór ten opowiada 
historię miłosną (por. Kunnisch 1969: 71-79). Tytułowa para - „ten i ta”, czyli on i ona - spotykają się na łące w dolinie (ona przyszła pierwsza i długo nań czekała) i od tego momentu akcja nabiera tempa: od tak zwanego „przełamania lodów” (eis weg) po fizyczne zbliżenie zwieńczone rosą, która okrywa namiętnych kochanków, osiadając w dolinie. Metonimiczna motywacja Bernsteina zaowocowała powtórzeniem przede wszystkim formalnego mechanizmu ograniczającego. Pierwszy wers w przekładzie prezentuje się następująco:

kam der und die kam und die kam vor ihm ins tal und

(ej [Ernst Jandl w: Bernstein 2013: 154)

can dew and die can and die can tie his sin tap and

(cb [Charles Bernstein], w: Bernstein 2013: 155)

Przekład Bernsteina polega na odtworzeniu tej samej liczby trzyliterowych słów w takim samym układzie, przy jednoczesnym zachowaniu - tak, jak to możliwe, by otrzymać jednostki leksykalne ze zbioru języka angielskiego tych samych liter w tym samym szeregu (homonimia interlingwalna war - war czy die - die) lub w formie anagramów (ins - sin). Wybrane słowa (kam, ihm i inne) zostały natomiast poddane ekwiwalencji semantycznej. Punkt ciężkości opowieści przeniesiono jednak na rosę i jej apokaliptyczny wymiar - rosa symbolizuje tu koniec, śmierć (zapewne uczucia kochanków).

Adeena Karasick opisuje ten przekład Bernsteina jako „homofoniczny”, dopatrując się w nim motywacji kabalistycznej, w której mechanizm kreacyjny jest oparty na hebrajskim systemie numerologii:

Zgodnie z zasadami gematrii numeryczna ekwiwalencja pary wyrazów ujawnia wewnętrzną relację kreacyjnych potencjałów każdego z nich. Dokonany przez Bernsteina homofoniczny przekład wiersza der und die Ernsta Jandla zmusza nas do odkrycia takich relacji w każdej z 338 trzyliterowych syntagm. $\mathrm{Na}$ przestrzeni dwudziestu sześciu wersów (po 13 wyrazów w każdym), za pomocą nieco wypaczonej abulafiańskiej metody chochmat ha-ceruf (nauki o kombinacji spółgłosek) czy drachimceruf ha-otijot (sposobów permutacji liter), Bernstein odprawia święty rytuał kombinacji (Karasick 2010: 403-404).

Marjorie Perloff natomiast podkreśla kontekst powstania tego „przekładu" (sama bierze go w cudzysłów), który również wiąże się przynajmniej pośrednio z motywami kabalistycznymi. Tekst dew and die wchodzi bowiem w skład Shadow time, czyli libretta do opery związanej z życiem 
i twórczością Waltera Benjamina (por. Perloff 2009: 705), a dokładniej jego części zatytułowanej The Doctrine of the Similiar, nawiązującej do eseju Benjamina z 1933 o tym samym tytule (Nauka o podobieństwie). W eseju niemiecki filozof rozważa kwestię zdolności dostrzegania podobieństw: zmysłowych (cielesnych) i niezmysłowych (językowych). Rozwój arbitralnie kodowanej mimetyczności języka, którego konsekwencją jest pismo, doprowadził do tego, że ,sfera percepcji człowieka zawiera już tylko drobne pozostałości owych magicznych korespondencji i analogii” (Benjamin 2011a: 285), o których między innymi mówi kabała. Mimetyczny aspekt języka wymaga dziś swojego medium - czyli arbitralnego, niezmysłowego aspektu semiotycznego:

cały mimetyczny aspekt języka stanowi pewną ugruntowaną intencję, która pojawić się może jedynie na gruncie czegoś obcego, a mianowicie tego, co semiotyczne, co komunikujące w języku. I tak litery tekstu pisanego stanowią grunt i zasób, bez którego rebus nie może się uformować. Tak też związek sensu, tkwiący w dźwiękach danego zdania, stanowi grunt i zasób, dzięki któremu w ułamku chwili, niczym błyskawica, z jakiegoś brzmienia może wyłonić się podobieństwo (por. Benjamin 2011b: 276).

Bernstein rozważania te ilustruje między innymi wierszem Jandla, metonimiczne powtarzając w przekładzie jego kreacyjny mechanizm, który w kontekście powyższych rozważań zdaje się wskazywać na chęć przywołania owych rozbłyskających w ułamku sekundy, z ducha kabalistycznych, wewnętrznych relacji opartych na podobieństwie.

Tau und tod, przekład przekładu Bernsteina dokonany przez Miriam Rainer, jest powtórzeniem powtórzenia, zostaje bowiem zachowana zasada przyległości na zmianę alfabetycznej i semantycznej, czyli tego Benjaminowskiego połączenia aspektu mimetycznego i semantycznego:

käm tau und tod käm und tod käm fad hiß ins tob und (mr [Miriam Rainer], w: Bernstein 2013: 156).

gdzie hiß jest quasi-fonetycznym ekwiwalentem his (,jego"), po niemiecku nic jednak nie znaczy (występuje tylko jako nazwisko), tod (,nieżywy”) należy do tego samej grupy semantycznej co Bernsteinowskie die (,umierać"). U Jandla to odpowiednio $\mathrm{ihm}$ (zaimek osobowy w celowniku - odpowiednik polskiego „nim”) oraz żeński rodzajnik określony die, zatem przekład Rainer za oryginał przyjmuje tekst Bernsteina, ale metonimiczny 
gest powtórzenia zakładający rekonstrukcję kreacyjnego mechanizmu oryginału odnosi się do mechanizmu przekładu, jaki przyjął Bernstein, tłumacząc tekst Jandla.

\section{Oryginało-przekład czyli powtórzenie in statu nascendi}

Mówiąc o przekładzie motywowanym metonimiczną chęcią odtwarzającego powtórzenia, przywoływałam dotychczas przykłady tłumaczeń autonomicznych, to znaczy takich, których tekst był graficznie wydzielony w osobną całość i tylko za pomocą paratekstów sugerował intertekstualną (przekładową) relację z oryginałem. Wiedeńscy tłumacze we współpracy z Bernsteinem zaproponowali natomiast formę dualistyczną, łączącą w sobie zarówno oryginał, jak i tłumaczenie. Taki „oryginało-przekład” poprzez zilustrowanie procesu przekładu dąży do wypełnienia głównego postulatu translatorskiego VERSATORIUM (i Bernsteina), czy raczej antypostulatu, mówiącego o nieprodukowaniu finalnych rezultatów. Wprawdzie połowa tekstu jest rzeczywiście formą przekładu, a więc - zdawałoby się - rezultatem, ale formalny chwyt prezentujący ściśle spleciony duet tekstowy przywołuje na myśl tłumaczenie interlinearne, skreślone ołówkiem na marginesie lub między kolejnymi wersami tekstu wyjściowego. Tłumaczenie pierwsze, filologiczne, niedoskonałe - a więc niefinalne. Takie podejście wpisuje się w teoretyczne ramy przekładu metonimicznego:

Przekład metonimiczny zakłada obligatoryjnie jukstapozycję: paralelną lekturę z oryginałem, z którym podejmuje żywy intertekstualny dialog. Wykracza zatem poza dyskurs podobieństwa i substytucji (mimesis) i sytuuje się w dyskursie przyległości i kombinacji. Konfrontacja z oryginałem okazuje się niezbędna dla pełnego odczytania przekładu jako artystycznego eksperymentu. Tekst źródłowy jest zarówno pierwszą przyczyną, pre-tekstem przekładu, jak i jego przylegającym dopełnieniem ${ }^{18}$.

18 Brzostowska-Tereszkiewicz (2012: 65). Wprawdzie w wielu miejscach nie zgadzam się z Brzostowskiej rozumieniem przekładu metonimicznego, między innymi ze względu na rozmywanie granic pomiędzy poszczególnymi tropami (poprzez włączenie do definicji metonimii pojęć fetyszyzacji i przesadnej ekspozycji, które, jak starałam się wykazać, należą do synekdochy i hiperboli), ale akurat powyższa uwaga jest zbieżna $\mathrm{z}$ reprezentowanym przeze mnie w tej pracy stanowiskiem. 
VERSATORIUM zaproponowało dwa sposoby takiej metonimicznej, dualistycznej prezentacji oryginało-przekładu: pierwszy powtarza niektóre elementy poprzez ich przepisanie, tłumacząc tylko części wersów, drugi zaś niemal dosłownie imituje wspominany brudnopis tłumacza, z wpisaną linijka w linijkę pierwszą wersją przekładu. Pierwszy stanowi kontaminację oryginału i przekładu pod względem formalnym, nie przekraczając objętości tego pierwszego (sygnowany jest zgodnie z przyjętym w książce systemem kodyfikacji zarówno inicjałami autora, cb, jak i tłumacza, pw), drugi zaś objętościowo dokładnie podwaja wymiar tekstu oryginalnego.

Oprócz VERSATORIUM wiersze Bernsteina przełożyła na język niemiecki także inna grupa tłumaczy $-\mathrm{z}$ Niemiec ${ }^{19}$. Publikacje ukazały się niemal w tym samym czasie i obie zostały uhonorowane prestiżową nagrodą w dziedzinie przekładu literackiego: Poesiepreis der Stadt Münster ${ }^{20}$. Co ciekawe, mimo podobnego sukcesu grupa VERSATORIUM zdaje się w krytyce funkcjonować jako projekt pionierski i szczególnie ambitny, wobec czego sytuujący tę drugą publikację w trudnej pozycji ,zwykłego, tradycyjnego". Recenzent obu tomów odczuł nawet potrzebę zaznaczenia, że choć przekład niemieckich tłumaczy jest ,czysto literacki”, to ,przecież nie mniej uderzający" (Kuhlbrodt 2015) - jak gdyby owa czysta literackość stała się synonimem kompromisu czy wręcz przekładowej porażki.

Wiersz A Test of Poetry został przełożony zarówno przez Waterhouse'a, jak i grupę niemieckich tłumaczy Amslinger/Lange/Lupette/Traxler. Dla porównania przytoczę pierwszą strofę oryginału i obu przekładów (wytłuszczenia moje):

A Test of Poetry (Charles Bernstein)

What do you mean by rashes of ash? Is industry systematic work, assiduous activity, or ownership of factories? Is ripple agitate lightly? Are we tossed in tune when we write poems? And what or who emboss with gloss insignias of air? (Bernstein 1999: 52)

19 Owocem ich pracy jest tom Bernstein 2014.

${ }^{20}$ Nagroda ta przyznawana jest autorowi poezji i jego thumaczowi (tłumaczom) za - jak podaje w oficjalnych materiałach kapituła - ,niezależny i adekwatny" przekład, co w kontekście tak różnych przekładów obu grup tłumaczy stanowi interesujący precedens. 


\section{Ein Test der Poesie (Norbert Lange)}

Was meinen Sie mit Ausschlägen aus Asche? Ist Industrie ein Wirtschaftszweig, Massenfabrikation oder Eigentum von Fabriken? Ist Kräuseln leicht schütteln? Sind wir Dichter dann in Harmonie geschleudert? Und wer oder was trägt Lackinsignien aus Luft?

(Bernstein 2014: 15)

\section{B Test of Poetry (cb, pw)}

What do you mean by überallen Wipfeln? Is Industrie industriousness or dust or a river? And Rüpel a Russian word? Are we tossed in tune by Tunesische Gedichte? And why and when geht dann und wann ein weißer Elefant?

(Bernstein 2013: 114)

Zaznaczone fragmenty zostały przeniesione w niezmienionej formie z oryginału - są to miejsca, w których literalnie ,,prześwituje” tekst wyjściowy, widoczne szwy tej literackiej kontaminacji. Jest to jednocześnie zapis pośredniego etapu przekładu - w którym tłumacz nie zdołał jeszcze wypracować form całego tłumaczenia - oraz ważne pytanie o zadanie tłumacza. Taki podwójny zapis ,,przekłado-oryginału” może sugerować, że przekład oznacza przeniesienie Innego oryginału w kontekst kultury języka poprzez metonimiczną substytucję środowiska (czyli w tym przypadku dosłownie słów i zdań otaczających te przeniesione fragmenty). Tytuł przekładu - B Test of Poetry - jest jednocześnie sugestią istnienia równoprawnych (wymiennych) tekstów, z oryginałem funkcjonującym jako wersja A, przekładem zaś jako wersja B. Litera „B” jest też homonimem trybu rozkazującego od „być” - be, staje się więc imperatywem przetestowania poezji i poetyckości za pomocą przekładu właśnie - w myśl słynnej wypowiedzi Frosta, mówiącej o tym, że poezją jest wszystko to, co zostaje zgubione w przekładzie.

Drugi rodzaj prezentacji oryginało-przekładu to, jak już wspomniałam, formalne podwojenie zakładające prezentację obu wersji - zarówno wyjściowej, jak i thumaczenia, w zapisie przypominającym przekład interlinearny. Wiersz Azoot d'Puund w pierwszym momencie sugeruje użycie języka obcego (sztucznego; jeden z recenzentów wskazuje na hybrydę angielszczyzny Chaucera i języka afrikaans - por. Pohl 2000) i wymaga specjalnego trybu lektury, niejako przekładowej: 
Azoot d'Puund, wiersz z tomu Poetic Justice, jest poruszającym przykładem intencjonalnego wymazania znaczenia oraz kontaminacji z szumem normatywnego dyskursu poetyckiego (...). Posiłkując się naturalnym zmysłem interpretacji, jesteśmy w stanie rozpoznać pod warstwą szumu nieartykułowalnych zbitek literowych istniejące niegdyś sensowne słowa i wersy (...). I jeśli jakkolwiek, kiedykolwiek dotrzemy wreszcie do oryginalnych (podkreślenie moje - I.O.), sensownych wyrazów (...) należy pamiętać o tym, że te słowne manipulacje były zabiegiem celowym (Lutzkanova-Vassileva 2015: 143).

Pierwsze wersy oryginału wyglądają następująco:

iz wurry ray aZoOt de puund in reducey ap crrRisLe ehk nugkinj sJuxYY senshl. Ig si heh hahpae uvd $r$ fahbe haht si gidrid (Bernstein 1979: 25-26).

W wersji niezmienionej weszły one do przekładu, gdzie kolejne wersy rozdziela tłumaczenie, które jest jednocześnie sugerowanym przez Lutkanovą-Vassilevą przekładem wstecznym - powtórzeniem odwrotnym (skierowanym wstecz, a więc w rozumieniu Kierkegaarda czymś w rodzaju wspomnienia tego, co już było):

Iz wurry ray aZoOt de puund in reducey ap crrRisLe ehk nugkinj sJuxYY senshl. I would say Ezra Pound in reduced form as Chris Lee / grizzly is nothing but Jux and senselessness. Ig si heh hahpae uvd $\mathbf{r}$ fahbe haht si gidrid. Ich sehe Hahpae auf der Fahrbahn, Acht sie gibt. / Is she happy? (cb, aen [Charles Bernstein, Astrid Nischkauer], w: Bernstein 2013: 45).

Tak się dzieje jednak w pierwszym wersie, drugi zaś jest już twórczym (aberracyjnym) odtworzeniem funkcjonalności tego mechanizmu, niemiecki wers sprawia bowiem tylko pozory deszyfracji oryginalnego anagramu, ale dokładne prześledzenie zasobu liter pokaże, że np. u Bersteina nie występuje litera „c” zawarta w słowie ich itd. Znów więc mamy do czynienia z redukcją oryginału do elementu kreacyjnego i zaimplementowaniem go w przekładzie w taki sposób, by powtórzenie było przede wszystkim tworzeniem.

\section{Po słowie, po tekście}

Opisana powyżej sytuacja przekładowa ujęta $\mathrm{w}$ ramy tropicznych kategorii przekładu to próba zaprezentowania w praktyce zastosowania analizy motywacji tłumacza, która opis strategii i tego, „,co” się wydarzyło w przekła- 
dzie, traktuje jako narzędzie do odpowiedzi raczej na pytanie „dlaczego”, a nie ,z jakim efektem”. W przypadku thumaczenia metonimicznego za owym „dlaczego" kryje się afektywny stosunek do Innego, jakim jest miłość powtórzenia (w rozumieniu Kierkegaarda), tutaj wyrażona w procesie odtworzenia pierwotnego mechanizmu kreacyjnego tekstu. Z oczywistych względów zaprezentowałam obszerniejsze zastosowanie tylko jednego z tropów, moje dotychczasowe badania pokazały jednak, że wszystkie pięć mają potencjał operatywny.

Nie należy jednak tych tropów traktować hermeneutycznie. Krytyk tropiczny próbuje zrekonstruować motywacje tłumacza, a nie możliwe strategie, które - jak się wydaje - narzuca tekst. Łatwo jest bowiem popaść w pułapkę metapoziomów: jeśli dany tekst naszpikowany jest ironią, nie oznacza to, że jego tłumacz będzie ironiczny tylko dlatego, że ową oryginalną ironię oddał w przekładzie. Nawet jeśli zrozumiemy afektywny charakter prezentowanych tropicznych postaw - na przykład to, że przekład metonimiczny to taki, który redukuje tekst do mechanizmu kreacyjnego i próbuje za pomocą środków języka i kultury docelowej wprawić w ruch ten sam mechanizm, by od-tworzyć przekład - nie znaczy to, że każdy tekst, który posiada ,gołym okiem" rozpoznawalny mechanizm, zostanie przełożony w ten sposób. $\mathrm{Na}$ przykład kolaże Herty Mueller zdawałyby się idealnym kandydatem dla takiego przekładu - mechanizmem kreacyjnym jest tu forma zarówno na poziomie tekstu (rymy, aliteracje), jak i na poziomie jego wizualnej reprezentacji, oryginalnie zostały bowiem opublikowane jak faksymile ręcznie wydzieranych i przyklejanych elementów. A jednak w strategii polskiego thumacza Leszka Szarugi łatwo dostrzec motywację synekdochiczną, fetyszyzującą jeden element tej poezji, mianowicie anegdotę, historie opowiedziane przez autorkę. Elementy formalne - wspomniane rymy, aliteracje czy też krój czcionki oraz rozmieszczenie jej na stronie - zostały pominięte, a anegdota podniesiona do rangi części reprezentującej całość. A zadaniem krytyka tropicznego jest poszukiwanie motywacji przez analizę zaistniałego aktu przekładu i w tym sensie nie istnieje dlań hermeneutyka oryginału, która podsuwałaby gotowe rozwiązania. Co więcej, tłumacz - i tu do głosu dochodzi „czynnik ludzki” (na który składać się mogą osobiste doświadczenie, nastrój, ale także wymagania czy ingerencje ze strony wydawcy czy samego autora) - może prezentować różne strategie o odmiennych motywacjach. Nie należy przyklejać tropicznej łatki raz na zawsze. 


\section{Bibliografia}

Benjamin W. 2011a. O zdolności mimetycznej, przeł. A. Lipszyc, „Literatura na Świecie” 5/6, s. 288-292.

_ 2011b. Nauka o podobieństwie, przeł. A. Lipszyc, „Literatura na Świecie” 5/6, s. $281-287$.

2011c. Zadanie tlumacza, przeł. A. Lipszyc, „Literatura na Świecie” 5/6, s. 27-41. Bernstein Ch. 1979. Poetic Justice. Baltimore: Pod Books.

1999. My way: Speeches and Poems, Chicago, London: The University of Chicago Press.

2001, Words and Pictures, w: Ch. Bernstein, Content's Dream: Essays 1975-1984, Los Angeles: Sun and Moon Press.

- 2013. Gedichte und Übersetzen, Versatorium, Band 1.1. Wien: Edition Korrespondenzen.

— 2014. Angriff der schwierigen Gedichte. Ausgewählte Gedichte, zweisprachig, z języka amerykańskiego przeł. T. Amslinger, N. Lange, L.W. Lupette, M. Traxler, Wiesbaden.

Bloom H. 2003. Mapa przekrzywień, przeł. A. Lipszyc, „Literatura na Świecie” 9/10, s. 5-34.

Borges J.L. (1978). Pierre Menard - autor Don Kichota, w: J.L. Borges, Opowiadania, przeł. Z. Chądzyńska, posłowiem opatrzył R. Kalicki, Kraków: Wydawnictwo Literackie. Brzostowska-Tereszkiewicz T. 2012. Przekład jako metonimia, „Między Oryginałem a Przekładem" XVIII, s. 59-73.

Burke K. 1962. Grammar of Motives, Berkeley: University of California Press.

Chesterman A. 1997. Memes of Translation, Amsterdam: John Benjamins.

Dengg J. 2013. w: Ch. Bernstein, Gedichte und Übersetzen, Wien: Edition Korrespondenzen, s. 10-11.

Donovan T. 2015. Interview with Charles Berstein, „Harriet. A Poetry Blog”, https://www. poetryfoundation.org/harriet/2010/04/interview-with-charles-bernstein-part-i [dostęp: 15 czerwca 2015].

Gray K. 1994. review of Douglas Robinson, The Translator's Turn. „The Modern Language Review" vol. 89, s. 178-79.

Grillmayr J. 2013. Eine Schildkröte an der Universität der Hasen, „derStandard.at“, 9maja, http://derstandard.at/1363709824464/Eine-Schildkroete-an-der-Universitaet-der-Hasen [dostęp: 15 maja 2015].

Karasick A. 2010. In the Shadow of Desire: Charles Bernstein's Shadowtime and Its Kabbalistic Trajectories, w: S.P. Miller, D. Morris (red.), Radical Poetics and Secular Jewish Culture, Tuscaloosa, Alabama: University of Alabama Press, s. 397-408.

Kierkegaard S. 2000. Powtórzenie. Przedmowy, przeł. i oprac. B. Świderski, Warszawa: W.A.B.

Kuhlbrodt J. 2015. Zur Charles Bernsteins Angriff der schwierigen Gedichte, ,Signaturen" Forum der Autonomen Poesie, http://signaturen-magazin.de/charles-bernstein--angriff-der-schwierigen-gedichte.html [dostęp: 10 maja 2015]. 
Kunnisch H. 1969. Vom Ansprung der Dichtung, „Welt und Wort” 24, s. 71-72.

Lutzkanova-Vassileva A. 2015. The Testimonies of Russian and American Postmodern Poetry: Reference, Trauma and History, London-New York: Bloomsbury Academic.

De Man P. 1986. Autobiografia jako od-twarzanie, przeł. M.B. Fedewicz, „Pamiętnik Literacki" 2, s. 307-318.

Marcinkiewicz P. 2011. Poeci J-E-Z-Y-K-A, ,Odra” 2, s. 52-58.

Neubert A., Shreve G.M. 1997. Basic Issues in Translation Studies: Proceedings of the Fifth International Conference. Kent Forum on Translation Studies. Kent. Ohio: Institute for Applied Linguistics.

Okulska I. 2015. Pod pozorem autora, pod pozorem tłumacza-nieważne, kto urodzi, ważne, kto wychowa, w: A. Kwiatkowska, L. Marzec, J. Wójcik (red.), Twórczość niepozorna. Szkice o literaturze, Kraków: Wydawnictwo Pasaże, s. 322-341.

Pawelec M. (2012). Douglas Robinson and the Somatic Approach to Translation, ,Między Ooryginałem a Przekładem" XVIII, s. 25-37.

Perloff M. 2009. Constraint, Concrete, Citation: Refiguring History in Charles Bernstein's Shadowtime, „Poetics Today” 30 (4), s. 693-717.

Pohl R.D. 2000, Strong Focus on the Language, „Buffalo News”, 7 maja, http://epc. buffalo.edu/authors/bernstein/books/republics.html.

Robinson D. 1991. Translator's Turn, Baltmiore-London: John Hopkins University Press.

Stark D. 1992. Recenzja Translator's Turn, „Language” 68 (4), s. 867-868.

Zhou J. 2014. Versatorium „Playbook” Explores Translation, „Harvard Crimson”, 15 kwietnia, http://www.thecrimson.com/article/2014/4/15/charles-bernstein-peter-waterhouse-versatorium-playbook-jack-zhou/ [dostęp: 15 listopada 2014]. 